Article

\title{
The New Ecological Paradigm, Pro-Environmental Behaviour, and the Moderating Effects of Locus of Control and Self-Construal
}

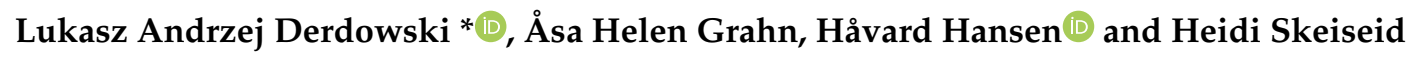 \\ The Norwegian School of Hotel Management, University of Stavanger, 4036 Stavanger, Norway; \\ Asa.Grahn@uis.no (Å.H.G.); Havard.hansen@uis.no (H.H.); Heidi.v.skeiseid@uis.no (H.S.) \\ * Correspondence: lukasz.a.derdowski@uis.no
}

Received: 21 August 2020; Accepted: 15 September 2020; Published: 18 September 2020

\begin{abstract}
Acquiring a better understanding of what drives pro-environmental and sustainable behaviour is important for both researchers and practitioners alike. The purpose of this paper is to explore the moderating role of locus of control and self-construal on the relationship between pro-environmental beliefs and pro-environmental consumer behaviour. We explicitly model the endorsement of the New Ecological Paradigm (NEP) as a predictor of three specific types of environmental behaviour - travel, purchasing and day to day activities. The results show a positive and significant association between the endorsement of NEP and a person's pro-environmental traveling behaviour, purchasing behaviour and day to day activities. Moreover, we find that the effects are moderated by a person's locus of control, specifically, it remains positive and significant only for people with an internal locus of control. However, we found no moderating effect of a person's self-construal on the association between NEP and pro-environmental behaviour. The findings are important in the continuing work to understand what is limiting consumers to behave according to their beliefs. Practical and theoretical implications of the results as well as suggestions for future research are presented.
\end{abstract}

Keywords: new ecological paradigm; locus of control; self-construal; pro-environmental behaviour; moderator effect

\section{Introduction}

For marketers of "green" products and services and for public policy-makers attempting to swing the public's behaviour in an eco-friendly direction, the gap between one's attitudes/beliefs/intentions and behaviour has been a several decade long challenge [1-5]. In psychology, this gap is neither new nor limited to pro-environmental behaviour, but for both marketers and policy-makers who have focused on developing pro-environmental attitudes and beliefs among customers and the general public, a sense of despair develops when a change in these is not accompanied by a corresponding significant behavioural change. For example, the fact that attitudes are commonly conceived of as a stable set of beliefs about an object that predisposes the individual to behave in a positive/negative way towards that object [6] often leaves them in dismay when attitudes and behaviours do not match. One of the suggested explanations for this inconsistency between cause and effect variables is lack of measurement specificity, which means that instead of scrutinizing the effects of behaviour-specific attitudes/intentions/beliefs on specific behaviours, researchers and practitioners alike have focused on more general environmental attitudes or beliefs and found either nonsignificant behavioural effects, or results that have been inconsistent [2,3,7-9]. However, in this paper, we argue that the New Ecological Paradigm (NEP) [10], which is a belief based, value-oriented predictor of consumer intentions to behave in a pro-environmental way, has pro-environmental effects also across different 
behaviour-specific levels. Motivated by previous research [11], we also suggest that the NEP-behaviour relationship is influenced by individual differences. Research has linked cardinal traits like openness and conscientiousness to environmental outcome variables such as emissions-reducing behaviours $[12,13]$ and environmental engagement [14]. In this study, we suggest that locus of control and self-construal moderate the NEP-behaviour relationship, and the succeeding paragraphs present the background for our assumptions in more detail.

\section{Literature Review and Hypotheses Development}

\subsection{The New Ecological Paradigm and Pro-Environmental Behaviour}

Pro-environmental behaviour is any behaviour that "harms the environment as little as possible or even benefits it" $[15,16]$ (p. 309), either performed in public or in the private domain, in the natural or the built world [17]. Research on pro-environmental behaviour has to date identified a variety of causal variables, and already 20 years ago Stern suggested that these could be grouped into a quartet consisting of attitude variables, contextual factors, personal capabilities, and habits or routines [18]. Stern discusses how types of pro-environmental behaviour differ along some important lines and explicitly describes environmental activism, non-activist behaviour in the public sphere, private sphere environmentalism, and other significant environmental behaviours. These different groups of causal variables, and the different kinds of pro-environmental behaviours, contribute to the aforementioned attitude-behaviour inconsistencies in both research and practical initiatives aimed at behavioural change. When non behaviour-specific predictor variables (e.g., attitudes) are modelled against a specific kind of behaviour that is not related to these kinds of general variables, results are likely to be nonsignificant [9].

Along with an increased awareness of environmental issues over the last 50 years, some researchers also predicted the dawn of a new world view with ecological issues placed centre stage, and Dunlap and colleagues (amongst others) suggested that the New Environmental Paradigm (NEP) is representative for these changing beliefs [10]. In brief, NEP represents higher order beliefs about the human-environment relationship. It suggests that humans depend on a natural world that is ecologically balanced and that there is a limit to economic growth. Both NEP and the extensively used attitude concept rest on beliefs as a basic building block, but then differ significantly as to what kind of beliefs are in focus. Although attitude-behaviour models typically focus on beliefs related to an object or a certain behaviour $[19,20]$, NEP draws on overarching beliefs about the world we live in [21]. Whether we call these higher order beliefs or more fundamental ecological beliefs, they still represent our perception of how humans should relate to the environment. This implies that while attitudes are always measured in relation to a specific object (e.g., a product, a person, a behaviour, an idea), the measurement "object" of NEP is always the same. By this, we mean that NEP and the application of the NEP-scale both lift the explanatory variable to a higher order level and also ensures a consistent measure of these beliefs when held against different behavioural situations. Thus, we find reason to believe that the lack of measurement specificity suggested to cause the aforementioned attitude-behaviour inconsistencies are less likely to cause similar problems for NEP-behaviour relationships.

The reasons we suggest NEP should influence a consumer's pro-environmental behaviour across more than one specific domain, are several. First, and following the same line of reasoning that applies to attitude-behaviour models [20], is that people are prone to act in accordance with their beliefs. As for NEP, this implies that we are likely to adopt a behaviour that ensures a belief-behaviour consistency, and behaviours that violate this consistency may result in cognitive dissonance [22] or imbalance [23].

As a strong adherence to the basics of NEP is a more overarching and far-reaching belief than a strong attitude towards a specific object, like a specific behaviour, it is likely to influence a far broader range of behaviours than more specific attitudes. Or stated differently, where specific attitudes lead to specific behaviours, our fundamental and basic world views reinforce a wider range of behaviours in 
line with these [24]. Furthermore, Vested Interest Theory (VIT) describes how a consumer's interest in an object depends on how it corresponds with his/her value orientation, which is an individual characteristic [25]. Values serve as "fundamental guiding principles which determine behaviour across situations" (p. 367, [25]), and value-relevant involvement motivates people to act in line with their general beliefs [26]. As NEP is closely related to values [18], we argue that strong beliefs in issues comprised in NEP serve as the same fundamental guiding principle that shape our behaviour across a variety of situations.

Finally, a multitude of studies have shown that NEP is significantly related to behavioural intentions, and various self-reported and observed pro-environmental behaviours [11,27]. Pahl et al. [28] found that across 21 self-reported behaviours related to the environment, NEP had a significant and positive effect. That is, the more participants endorsed NEP, the more pro-environmental behaviours they reported. According to Xiao et al. (p. 56 [24]), NEP is "the most widely used measure of environmental concern in the literature," and the authors also state that the widespread number of studies modelling NEP as a driver of pro-environmental behaviours typically find that NEP is a powerful predictor of behaviour. For example, NEP has been applied in studies of tourism and recreation, and Wurzinger and Johansson [29] found that endorsement of NEP was significantly related to participating in tourism activities that meet all the criteria for ecotourism. Hedlund [30] found NEP to be a significant predictor of the willingness to accept economic sacrifices to protect the environment, and the intention to buy ecologically sustainable tourism alternatives. Mair [31] also found that travellers who scored high on NEP were those most likely to behave in a pro-environmentally friendly or responsible way and thereby more often voluntary offset their carbon footprint caused from their travels. Building on these previous results, our first hypothesis summarizes the preceding discussion as follow:

Hypothesis 1 (H1). An individual's endorsement of the New Ecological Paradigm (NEP) is positively associated with their pro-environmental behaviour (P-EB).

Although Hypothesis 1 is not novel per se, it offers a replication of previous research while, more importantly, also forming the baseline for our next suggested contribution to current knowledge. The aforementioned four groups of antecedents to pro-environmental behaviour suggested by Stern [18] include one he calls personal capabilities. Stern argues that these variables have limited explanatory power for a variety of pro-environmental behaviours, but that they can still be important when seen in relation to other predictors. We will argue that this makes the study of individual personality traits interesting, as these might "determine and reflect how a person responds to his or her environment" (p. 134, [6]). In the following paragraphs, we suggest that two such traits, locus of control and self-construal, will moderate the effect of NEP on pro-environmental behaviour.

\subsection{Locus of Control}

Locus of control is a personality trait that explains how people differ in the degree to which they believe they are themselves in control of the things that happen to them in life [32,33]. People with a predominant internal locus of control (ILC) believe that what happens to them is mainly a result of their own actions and behaviour ("I make things happen"). In contrast, people with a predominant external locus of control (ELC) think that there is little they can do to influence their path in life. They tend to believe that the outcomes of life events are primarily caused by external forces beyond their personal control ("things happen to me"). According to Rotter [33], people with an internal locus of control see a relationship between their behaviour and rewards, which is contrary to the attribution made by people with an external locus of control.

The sense of being in control of one's destiny is important for humans, whether or not they really are in control [34,35]. If we feel powerless, with outcomes being beyond our control, then the extent to which we will engage in active behaviour is likely to be affected. It is this difference between people who 
believe that things happen to them versus people who believe they can make things happen that we argue will affect people's likelihood to engage in pro-environmental behaviour. Specifically, we suggest that the relationship between NEP and pro-environmental behaviour is stronger for consumers with an ILC than an ELC. We have argued that NEP serves as a motivational force that drives consumers to pursue behaviour in line with their overarching beliefs. As such, NEP is likely to result in the same kind of behavioural effects as other kinds of intrinsic motivation, but it is also prone to be hampered or amplified by moderating forces that apply to these. This is in line with previous research, as for instance, Mehl and Hansen [36] found that locus of control moderates the effect of intrinsic motivation on sales persons information gathering. Somewhat simplified, Mehl and Hansen [36] suggest that when a person is motivated to perform an activity and also believes that they themselves are able to influence the outcome of that activity, the probability of them actually carrying out the behaviour is larger than if the motivation is there but the individual believes that outcome is externally controlled. McCarty and Shrum [37], in a study on recycling behaviour, found that beliefs about the importance of recycling were positively related to the propensity to recycle among individuals with an ILC. In our opinion, the same mechanism applies to the relationship between NEP and pro-environmental behaviour, and our second hypothesis is:

Hypothesis 2 (H2). An individual's locus of control (LOC) moderates the association between their endorsement of the NEP and pro-environmental behaviour. Specifically, the positive relationship between NEP and P-EB will be stronger for individuals with internal locus of control than for individuals with external locus of control.

\subsection{Self-Construal}

Self-construal is a self-definition focusing on how one relates to others. It distinguishes between whether we consider ourselves as autonomous and independent from others, independent self-construal, or part of a collective in close relationships with others, interdependent self-construal. The self-versus-other focus is in part a result of the values people grow up with [38-41] and whether the emphasis is on the "I," freedom and independence (independent self-construal) or more focused on the importance of being part of a "we" and the relationship to others [38,39]. Our self-construal will influence our focus in life, whether we are motivated to achieve the best solution for ourselves (independent self-construal) or the focus is on the best outcome for the social group we consider ourselves a part of (interdependent self-construal) [40]. As such, a person's self-construal has been shown to have a significant influence on the choices that we make [42] and how we relate to choices made by others [39,43]. In a study by Iyengar and Lepper [39], independent selves were more willing to engage in tasks chosen by themselves and less positive to perform tasks that had been chosen by others. Respondents with an interdependent self, on the other hand, were positive to perform tasks set by others. This work was later extended by Pöhlmann et al. [43], who found that the independent selves prefer self-relevant choices. These are choices that are made by them and where they are the primary recipient of the ensuing choice outcome.

Interdependent individuals are more prone to define their identity through relationships to others, the public component of the self is an important feature, and they emphasize actions that are appropriate in the eyes of others and thus are in line with expectations and social norms $[40,44]$. Thus, being interdependent is likely to have a value-expressive influence on behaviour, as efforts of impression formation or management can make consumers engage in activities that signal information about the self to others [45]. As the public component of the self is important, interdependent individuals are more concerned with expressing identity-relevant information through their behaviour. For example, consumers can approach products that are believed to positively influence their self-concept or distance themselves from products that threaten it [45]. As we have argued that NEP is an overarching belief structure, or a more fundamental world view than more context specific attitudes, we suggest that it is also related to our self-image and our shared self, and that interdependents therefore should be more 
inclined to behave in accordance with their level of NEP endorsement than independents. Consumers with an interdependent self-construal are more willing to make choices that may not be the best for them in instrumental terms, as long as it is the best choice for the society of which they consider themselves a part, as it signals their concern for the group and expresses important identity-related information. We, therefore, suggest that individuals with a predominantly interdependent self-construal will be more inclined to behave in accordance with their endorsement of NEP. Therefore, we hypothesize that:

Hypothesis 3 (H3). An individual's image of self (self-construal) moderates the association between their endorsement of the New Ecological Paradigm and pro-environmental behaviour. Specifically, the positive relationship between NEP and P-EB will be stronger for individuals with interdependent self-construal than for individuals with independent self-construal.

For an overview of the proposed hypotheses, the conceptual model is presented in Figure 1.
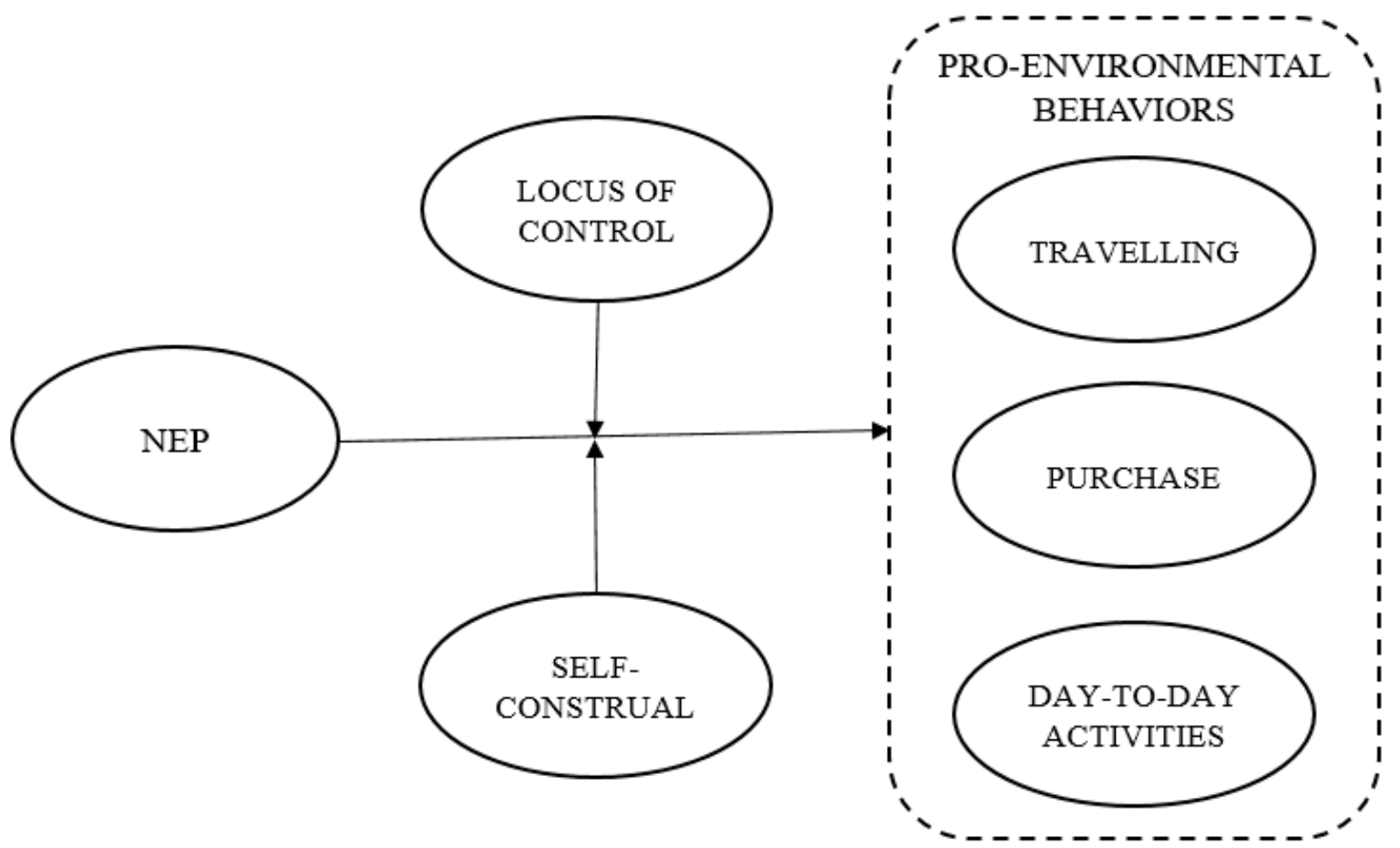

Figure 1. Conceptual model.

\section{Method}

\subsection{Data Collection and Sample}

To test the hypotheses, a nationwide sample of 200 Norwegian respondents was recruited using an online panel. The panel used in this study is owned and maintained by a professional market research company. The company recruits $50 \%$ of its panelists via phone and the rest via a range of online and offline sources to ensure diversity and representativeness. The questionnaire was distributed to panel members via the research company's digital distribution system. Respondents are incentivized to answer the questionnaire through a points system run by the company. Accumulated points can be exchanged into gift cards at a later stage. Respondents answered the questionnaire online. The questionnaire contained questions covering locus of control, self-construal, environmental behaviour and NEP. Mean age of respondents was 46.07 years (SD = 17.42), with the following distribution 19-29 years-26\%, 30-39 years-12\%, 40-49 years- $18.5 \%$ and $50-99$ years-43.5\%). The gender distribution was $44.5 \%$ males and $55.5 \%$ females. 


\subsection{Measures}

All independent and moderator variables were measured with Likert-type, multi-item scales, anchored as totally disagree (1) and totally agree (5). Prior to data collection, all scales were subject to a face validity check as they were discussed in a research group on sustainable consumption, which contributed to identifying and refining questions found to be confusing or ambiguous. An overview of utilized items is presented in Appendix A.

Locus of control was measured with five items adapted from Rotter [33]. Although Rotter used pairs of statements where respondents should choose the one in each pair that mostly described their belief, we redesigned the items into statements to which respondents should indicate the level of agreement. For example, although Rotter's scale asked respondents to select either "In my case getting what I want has little or nothing to do with luck" or "Many times, we might just as well decide what to do by flipping a coin." Our equivalent read "Many times, we might just as well decide what to do by flipping a coin," followed by a 5-point scale where respondents indicated their answer on a continuum from totally disagree to totally agree. High scores on the scale feature individuals with external locus of control, whereas low scores are characteristic for persons with internal locus of control. Obtained Cronbach's alpha is equal to $0.648(\mathrm{M}=2.77, \mathrm{SD}=0.75)$ and as such, it is marginally lower than the "acceptable" range of $0.65-0.80$ [46].

Six items for self-construal were adapted from Singelis [47]. High scores on the scale feature individuals with interdependent self-construal, while low scores are characteristic for persons with independent self-construal. Cronbach's alpha in this instance is equal to $0.643(\mathrm{M}=3.75, \mathrm{SD}=0.56)$.

The scale measuring respondents' endorsement of NEP was based on the 15-item scale reported by Dunlap et al. [48]. Of relevance, prior research has validated the scale in the Norwegian context (e.g., [49]). For a one-factor solution, the Cronbach's alpha is equal to $0.836(\mathrm{M}=3.69, \mathrm{SD}=0.60)$.

For the dependent variable, i.e., pro-environmental behaviour, three separate measures were developed for the purpose of this inquiry. Although their psychometric properties are mostly adequate, they were deliberately differentiated to capture persons' pro-environmental travelling behaviours ( 3 items, $\alpha=0.803, \mathrm{M}=2.09$ and $\mathrm{SD}=1.03$ ), purchasing behaviours ( 4 items, $\alpha=0.755, \mathrm{M}=2.86$ and $\mathrm{SD}=0.74$ ) and day-to-day activities ( 5 items, $\alpha=0.602, \mathrm{M}=3.39$ and $\mathrm{SD}=0.69$ ). We diversified the pro-environmental behaviour concept following Diekmann and Preisendörfer's [50] line of thinking saying that behaviours are often justified via low-versus high-cost situation explanations (i.e., time and effort needed to undertake an action, see also Steg et al. [51] for a relevant discussion around behavioural costs). For example, one may imply that travelling by train or bus instead of flying requires more time and effort on a person's side than taking a shorter shower. Moreover, the three different measures also cover three of the four different kinds of private sphere environmentalism discussed by Stern [18]. Specifically, traveling behaviour is an example of service purchases that are environmentally significant in their impact, purchasing behaviour like we measure it corresponds to Stern's [18] green consumerism, while our day-to-day activities largely resembles household waste disposal and recycling. The motivation behind measuring three different kinds of behaviour was to explicitly test our previous argument that NEP will predict a broader set of behaviours and that the measurement specificity problem argued to have caused nonsignificant relationships between attitudes and pro-environmental behaviour in previous research does not apply to NEP in the same way. Hence, we first asked respondents to use the last 12 months as a frame of reference and then indicate how often they had performed behaviours encapsulated in the three dependent variables. Responses were given on a 5-point scale, with options "Never, Rarely, Sometimes, Often and Always".

\subsection{Analytical Strategy}

All analyses were completed using IBM SPSS Statistics version 25. Moreover, path analyses were performed using the PROCESS macro (version 2.16.3 [52]), specifically Model 1 that is suitable for conducting tests of moderating effects. Furthermore, as much of social and behavioural science data tend to be non-normally distributed to a lesser or greater extent [53], we employed the bootstrapping 
technique that generates bias-corrected $95 \%$ confidence intervals for the estimated direct and conditional effects (here, 10,000 bootstrap samples were considered). Additionally, we supplemented our moderation-focused analysis by elaborating on Johnson and Neyman's ranges/areas of significance (i.e., the so-called floodlight test [54]).

\subsection{Common Method Bias}

As all our constructs are measured using the same methodology, the question of common method variance (CMV) or method bias deserves a comment [55]. As such, we controlled for CMV through both procedural (ex ante) and statistical (ex post) procedures [56]. With regard to procedural remedies, we followed the guidance provided by MacKenzie and Podsakoff [57]. Specifically, we emphasized to respondents that all their answers would be anonymous and treated with confidentiality to reduce their evaluation apprehension. Furthermore, we followed the recommendations of Tourangeau et al. [58] and refrained from using bipolar scales with negative numeric scale values (e.g., from -3 to 3 ) to avoid the positivity bias. On top of that, we reversed the wordings of some items to decrease respondents' urge to respond stylistically [59]. Finally, while designing the survey, a group of scholars discussed all survey items to avoid items' ambiguity and double-barreled questions [57]. Regarding statistical remedies, we applied Harman's single-factor test [55]. After entering all variables into an exploratory factor analysis (EFA), the unrotated factor solution revealed that no single element accounted for the majority of the variance (the largest identified factor explained $16.1 \%$ of variance, which is far less than the acknowledged cutoff value of 50\% [60]). Although the submitted procedures do not preclude the existence of the common method bias, they do, however, imply that method bias is unlikely to confound results of the current enquiry.

\section{Results}

\section{Hypotheses Testing}

Prior to testing the moderating effects of the presented personality traits, a set of simple regression analyses were performed to ascertain the relationships between an individual's endorsement of NEP and the three types of the pro-environmental behaviours. Along this line, our data reveal a positive and significant association between NEP and a person's pro-environmental traveling behaviours $(\beta=0.168$, $p$-value $=0.018$ and $\left.R^{2}=0.028\right)$. Similarly, a positive link was identified between NEP and a person's pro-environmental purchasing behaviours $\left(\beta=0.234, p\right.$-value $=0.001$ and $\left.\mathrm{R}^{2}=0.055\right)$. Finally, our results indicate a positive relationship between NEP and an individual's pro-environmental day-to-day activities $\left(\beta=0.320, p\right.$-value $=0.000$ and $\left.R^{2}=0.103\right)$. Taken together, these results render consistent support for our first, baseline hypothesis (H1).

Furthermore, estimated parameters of the moderating effect of an individual's locus of control on the aforesaid relation between NEP and pro-environmental behaviours are presented in Table 1 . Examination of the findings reveals the existence of a negative moderating effect of LOC, but only for pro-environmental behaviours focused on day-to-day activities $(\beta=-0.227, \mathrm{SE}=0.111$ and $p$-value $=0.041)$. Consequently, our second hypothesis $(\mathrm{H} 2)$ is partially supported.

However, since our moderator (i.e., locus of control) was continuous, we looked additionally through the post hoc analysis for the turning points for where exactly, in the absolute value of the moderator, the effect of the independent variable turns from nonsignificance to significance (for a prespecified alpha level of 0.05). As recommended by Hayes and others [61-63], this is done using the Johnson-Neyman technique. That being said, Table 2 offers evidence indicating that in fact the positive association submitted in Hypothesis 1 holds for all three types of the pro-environmental behaviours primarily at low (-1SD) and medium (Mean) levels of the locus of control scale. Additionally, an examination of Johnson and Neyman's test provides further evidence implying that the significant effect of NEP on one's travelling behaviours ranges from 0.760 to 0.247 only for values of the moderator (LOC) ranging from 1 to 3.035 (on a scale from 1 to 5), respectively. For scores of the moderator greater 
than 3.035, the effect of NEP on person's traveling behaviours was not significant $(p>0.05)$. In a similar fashion, the significant association between NEP scores and one's pro-environmental purchasing behaviours varies in effect from 0.606 to 0.232 for values of the moderator (LOC) ranging from 1 to 3.211, accordingly. A similar pattern can be observed as well with regard to the pro-environmental day-to-day activities criterion variable. In this instance, the estimated positive effect of NEP ranges from 0.791 to 0.233 for levels of reported locus of control oscillating between 1 and 3.459. As a result, these auxiliary analyses reveal that the positive effect of one's endorsement of NEP on the pro-environmental behaviour (regardless of its type) is likely to hold for individuals scoring at the lower end of the employed locus of control scale (i.e., for persons characterized as having the internal locus of control).

Table 1. Moderating effect of an individual's locus of control.

\begin{tabular}{|c|c|c|c|c|c|c|c|c|c|c|c|c|}
\hline & \multicolumn{12}{|c|}{ Dependent Variables } \\
\hline Intercept & $\begin{array}{c}2.093 \\
(0.072)\end{array}$ & $\begin{array}{l}29.036 \\
(0.000)\end{array}$ & 1.951 & 2.235 & $\begin{array}{c}2.861 \\
(0.051)\end{array}$ & $\begin{array}{l}55.832 \\
(0.000)\end{array}$ & 2.760 & 2.962 & $\begin{array}{c}3.388 \\
(0.045)\end{array}$ & $\begin{array}{l}74.564 \\
(0.000)\end{array}$ & 3.298 & 3.477 \\
\hline $\begin{array}{c}\text { Locus of } \\
\text { control }\end{array}$ & $\begin{array}{l}-0.186 \\
(0.099)\end{array}$ & $\begin{array}{l}-1.886 \\
(0.061)\end{array}$ & -0.381 & 0.008 & $\begin{array}{l}-0.104 \\
(0.073)\end{array}$ & $\begin{array}{l}-1.418 \\
(0.158)\end{array}$ & -0.248 & 0.041 & $\begin{array}{l}-0.158 \\
(0.069)\end{array}$ & $\begin{array}{l}-2.280 \\
(0.024)\end{array}$ & -0.294 & -0.021 \\
\hline \multirow[t]{2}{*}{$\begin{array}{c}\text { New } \\
\text { Ecological } \\
\text { Paradigm } \\
\times \text { locus of } \\
\text { control }\end{array}$} & $\begin{array}{l}-0.252 \\
(0.162)\end{array}$ & $\begin{array}{l}-1.562 \\
(0.120)\end{array}$ & -0.571 & 0.066 & $\begin{array}{l}-0.169 \\
(0.142)\end{array}$ & $\begin{array}{l}-1.191 \\
(0.235)\end{array}$ & -0.449 & 0.111 & $\begin{array}{l}-0.227 \\
(0.111)\end{array}$ & $\begin{array}{l}-2.052 \\
(0.041)\end{array}$ & -0.445 & -0.009 \\
\hline & \multicolumn{4}{|c|}{$\mathrm{R}^{2}=0.053 ; \mathrm{MSE}=1.021$} & \multicolumn{4}{|c|}{$\mathrm{R}^{2}=0.072 ; \mathrm{MSE}=0.518$} & \multicolumn{4}{|c|}{$\mathrm{R}^{2}=0.144 ; \mathrm{MSE}=0.409$} \\
\hline
\end{tabular}

Table 2. Conditional effect of New Ecological Paradigm (NEP) on dependent variables at values of the locus of control.

\begin{tabular}{|c|c|c|c|c|c|c|c|c|c|c|c|c|}
\hline $\begin{array}{l}\text { Locus of } \\
\text { Control as a } \\
\text { Moderator }\end{array}$ & \multicolumn{12}{|c|}{ Dependent Variables } \\
\hline$-0.747(-1 S D)$ & $\begin{array}{c}0.503 \\
(0.166)\end{array}$ & $\begin{array}{c}3.029 \\
(0.003)\end{array}$ & 0.176 & 0.831 & $\begin{array}{c}0.433 \\
(0.129)\end{array}$ & $\begin{array}{c}3.353 \\
(0.001)\end{array}$ & 0.178 & 0.688 & $\begin{array}{c}0.560 \\
(0.095)\end{array}$ & $\begin{array}{c}5.919 \\
(0.000)\end{array}$ & 0.373 & 0.746 \\
\hline 0.000 (mean) & $\begin{array}{c}0.314 \\
(0.117)\end{array}$ & $\begin{array}{c}2.697 \\
(0.008)\end{array}$ & 0.085 & 0.544 & $\begin{array}{c}0.307 \\
(0.090)\end{array}$ & $\begin{array}{c}3.396 \\
(0.001)\end{array}$ & 0.129 & 0.485 & $\begin{array}{c}0.390 \\
(0.072)\end{array}$ & $\begin{array}{l}5.405 \\
(0.000)\end{array}$ & 0.248 & 0.533 \\
\hline $0.747(+1 S D)$ & $\begin{array}{c}0.126 \\
(0.170)\end{array}$ & $\begin{array}{c}0.742 \\
(0.459)\end{array}$ & -0.209 & 0.460 & $\begin{array}{c}0.180 \\
(0.149)\end{array}$ & $\begin{array}{l}1.210 \\
(0.228)\end{array}$ & -0.114 & 0.474 & $\begin{array}{c}0.220 \\
(0.123)\end{array}$ & $\begin{array}{c}1.791 \\
(0.075)\end{array}$ & -0.022 & 0.463 \\
\hline
\end{tabular}

Furthermore, the obtained results indicate that an individual's image of self (self-construal) does not moderate the association between one's endorsement of NEP and various types of pro-environmental behaviours (see Table 3). Thus, the third hypothesis specifying the moderating role of one's self-construal is rejected. 
Table 3. Moderating effect of an individual's self-construal.

\begin{tabular}{|c|c|c|c|c|c|c|c|c|c|c|c|c|}
\hline & \multicolumn{12}{|c|}{ Dependent Variables } \\
\hline & \multicolumn{4}{|c|}{$\begin{array}{c}\text { Pro-Environmental Travelling } \\
\text { Behaviour }\end{array}$} & \multicolumn{4}{|c|}{$\begin{array}{c}\text { Pro-Environmental Purchasing } \\
\text { Behaviour }\end{array}$} & \multicolumn{4}{|c|}{$\begin{array}{c}\text { Pro-Environmental Day-to-Day } \\
\text { Activities }\end{array}$} \\
\hline & $\begin{array}{l}\text { Coeff. } \\
(S E)\end{array}$ & $\begin{array}{c}t \text { Test } \\
(p \text {-Value })\end{array}$ & LLCI & ULCI & $\begin{array}{l}\text { Coeff. } \\
(S E)\end{array}$ & $\begin{array}{c}t \text { Test } \\
(p \text {-Value })\end{array}$ & LLCI & ULCI & $\begin{array}{l}\text { Coeff. } \\
(S E)\end{array}$ & $\begin{array}{c}t \text { Test } \\
(p \text {-Value })\end{array}$ & LLCI & ULCI \\
\hline Intercept & $\begin{array}{l}2.093 \\
(0.074)\end{array}$ & $\begin{array}{l}28.379 \\
(0.000)\end{array}$ & 1.947 & 2.238 & $\begin{array}{l}2.860 \\
(0.053)\end{array}$ & $\begin{array}{l}54.383 \\
(0.000)\end{array}$ & 2.756 & 2.963 & $\begin{array}{l}3.385 \\
(0.047)\end{array}$ & $\begin{array}{l}71.411 \\
(0.000)\end{array}$ & 3.291 & 3.478 \\
\hline $\begin{array}{c}\text { New } \\
\text { Ecological } \\
\text { Paradigm }\end{array}$ & $\begin{array}{c}0.304 \\
(0.121)\end{array}$ & $\begin{array}{c}2.502 \\
(0.013)\end{array}$ & 0.064 & 0.543 & $\begin{array}{c}0.286 \\
(0.096)\end{array}$ & $\begin{array}{c}2.971 \\
(0.003)\end{array}$ & 0.096 & 0.476 & $\begin{array}{c}0.362 \\
(0.079)\end{array}$ & $\begin{array}{c}4.561 \\
(0.000)\end{array}$ & 0.206 & 0.519 \\
\hline Self-construal & $\begin{array}{c}0.081 \\
(0.145)\end{array}$ & $\begin{array}{c}0.556 \\
(0.579)\end{array}$ & -0.205 & 0.367 & $\begin{array}{l}-0.104 \\
(0.105)\end{array}$ & $\begin{array}{l}-0.995 \\
(0.321)\end{array}$ & -0.311 & 0.102 & $\begin{array}{l}-0.074 \\
(0.093)\end{array}$ & $\begin{array}{l}-0.793 \\
(0.429)\end{array}$ & -0.258 & 0.110 \\
\hline \multirow[t]{2}{*}{$\begin{array}{c}\text { New } \\
\text { Ecological } \\
\text { Paradigm } \times \\
\text { self-construal } \\
\end{array}$} & $\begin{array}{c}0.122 \\
(0.234)\end{array}$ & $\begin{array}{c}0.520 \\
(0.604)\end{array}$ & -0.340 & 0.584 & $\begin{array}{c}0.036 \\
(0.170)\end{array}$ & $\begin{array}{c}0.211 \\
(0.833)\end{array}$ & -0.300 & 0.371 & $\begin{array}{l}-0.010 \\
(0.136)\end{array}$ & $\begin{array}{l}-0.076 \\
(0.939)\end{array}$ & -0.278 & 0.257 \\
\hline & \multicolumn{4}{|c|}{$\mathrm{R}^{2}=0.032 ; \mathrm{MSE}=1.044$} & \multicolumn{4}{|c|}{$\mathrm{R}^{2}=0.061 ; \mathrm{MSE}=0.524$} & \multicolumn{4}{|c|}{$\mathrm{R}^{2}=0.106 ; \mathrm{MSE}=0.427$} \\
\hline
\end{tabular}

Additionally, estimated parameters representing the conditional effect of NEP on dependent variables at values of self-construal (Table 4), as well as the Johnson and Neyman's test, yield less robust and consistent results compared with the aforesaid evidence demonstrated in relation to $\mathrm{H} 2$. More specifically, the floodlight analyses show that the significant effect of NEP on one's travelling behaviours ranges from 0.271 to 0.384 only for distinctive values of self-construal, ranging from 3.479 to 4.403 (on a scale from 1 to 5), respectively. For scores of the moderator lower than 3.479 and greater than 4.403 , the effect of NEP on person's travelling behaviours was not significant $(p>0.05)$. In a similar vein, the positive association between NEP scores and one's pro-environmental purchasing behaviours spreads in effect from 0.264 to 0.310 for values of the self-construal ranging from 3.127 to 4.411. Finally, an alike pattern in the dataset can be observed with regards to the pro-environmental day-to-day activities. In this case, the asserted positive effect of NEP ranges from 0.377 to 0.351 for levels of reported self-construal oscillating between 2.371 and 4.833. As these results are likely to be of low practical significance (despite of being statistically significant [64]) and as they also lack a coherent theoretical explanation, we therefore refute the H3.

Table 4. Conditional effect of NEP on dependent variables at values of the self-construal.

\begin{tabular}{|c|c|c|c|c|c|c|c|c|c|c|c|c|}
\hline \multirow[b]{3}{*}{$\begin{array}{l}\text { Self-Construal } \\
\text { as a Moderator }\end{array}$} & \multicolumn{12}{|c|}{ Dependent Variables } \\
\hline & \multicolumn{4}{|c|}{$\begin{array}{c}\text { Pro-Environmental Travelling } \\
\text { Behaviour }\end{array}$} & \multicolumn{4}{|c|}{$\begin{array}{l}\text { Pro-Environmental Purchasing } \\
\text { Behaviour }\end{array}$} & \multicolumn{4}{|c|}{$\begin{array}{c}\text { Pro-Environmental Day-to-Day } \\
\text { Activities }\end{array}$} \\
\hline & $\begin{array}{c}\text { Effect } \\
(S E)\end{array}$ & $\begin{array}{c}t \text { Test } \\
(p \text {-Value) }\end{array}$ & LLCI & ULCI & $\begin{array}{c}\text { Effect } \\
(S E)\end{array}$ & $\begin{array}{c}t \text { Test } \\
(p \text {-Value })\end{array}$ & LLCI & ULCI & $\begin{array}{c}\text { Effect } \\
(S E)\end{array}$ & $\begin{array}{c}t \text { Test } \\
(p \text {-Value) }\end{array}$ & LLCI & ULCI \\
\hline$-0.559(-1 S D)$ & $\begin{array}{c}0.236 \\
(0.180) \\
\end{array}$ & $\begin{array}{c}1.309 \\
(0.192)\end{array}$ & -0.119 & 0.590 & $\begin{array}{c}0.266 \\
(0.127)\end{array}$ & $\begin{array}{c}2.099 \\
(0.037)\end{array}$ & 0.016 & 0.516 & $\begin{array}{c}0.368 \\
(0.101) \\
\end{array}$ & $\begin{array}{c}3.649 \\
(0.000)\end{array}$ & 0.169 & 0.567 \\
\hline 0.000 (mean) & $\begin{array}{c}0.304 \\
(0.121)\end{array}$ & $\begin{array}{c}2.502 \\
(0.013)\end{array}$ & 0.064 & 0.543 & $\begin{array}{c}0.286 \\
(0.096)\end{array}$ & $\begin{array}{c}2.971 \\
(0.003)\end{array}$ & 0.096 & 0.476 & $\begin{array}{c}0.362 \\
(0.079)\end{array}$ & $\begin{array}{c}4.561 \\
(0.000)\end{array}$ & 0.206 & 0.519 \\
\hline $0.559(+1 S D)$ & $\begin{array}{c}0.372 \\
(0.177)\end{array}$ & $\begin{array}{l}2.097 \\
(0.037)\end{array}$ & 0.022 & 0.721 & $\begin{array}{c}0.306 \\
(0.143)\end{array}$ & $\begin{array}{c}2.135 \\
(0.034)\end{array}$ & 0.023 & 0.589 & $\begin{array}{c}0.357 \\
(0.118)\end{array}$ & $\begin{array}{l}3.022 \\
(0.003)\end{array}$ & 0.124 & 0.589 \\
\hline
\end{tabular}

\section{General Discussion and Conclusions}

Extant research into consumers' voluntary pro-environmental behaviours consistently underlines the existence of the inconsistency between what people say (in order to express their attitudes, norms and values) and what they in reality do (so as to translate words into actions). This inconsistency is commonly known as the attitude-behaviour, intention-behaviour or values-action gaps [2,65-67]. As noted by Barnett et al. [68], narrowing this kind of gaps represents an actual challenge of both practical and theoretical significance if one aims to mobilize consumers towards greater engagement in voluntary pro-environmental acts. The unique role selected personality traits play in explaining 
the relationships presented is key to this paper. That is, we have argued and tested hypotheses of moderating effects of the individual's locus of control and image of self (self-construal) on the aforesaid relationship between consumer's NEP and adopted pro-environmental behaviours. The results point to several observations.

First, we argued that the measurement specificity issues claimed to confound a variety of previous studies on the attitude-behaviour relationship were unlikely to influence the relationship between NEP and pro-environmental behaviours. The reason, we suggested, is that even though NEP is a belief-based concept just like attitudes, these beliefs exist at a more fundamental level that concerns basic world views, self-image and overarching values. Hence, such a fundamental concept should not cause behavioural effects limited to only a small number of specific domains, but rather govern a larger set of behaviours and intentions directly related to the beliefs on which NEP is based. This is also what we found. Hence, one theoretical implication of our study is that when trying to explain pro-environmental behaviour, researchers can either focus on how behaviour-specific attitudes are linked to specific behaviour [7,9] or emphasize higher order beliefs like NEP and how these contribute to the explanation of a wider range of behaviours. In this way, our study contributes to the theoretical understanding of how pro-environmental behaviour is affected not only by very behaviour-specific attitudes but also by more overarching belief structures with ecological concerns at the centre of attention. The fact that we find NEP to predict three different kinds of pro-environmental behaviour [18] further underscores this argument.

Second, although NEP is a concept that covers consumer beliefs about human-environment relationships (e.g., [21]), it does not prescribe any behavioural solutions to the ecological concerns implicitly included in its measurement. As such, its motivational force also rests on consumers believing that they themselves are in control of carrying out activities needed to mitigate the poor state of the environment. Our results related to the moderating effect of locus of control support this, as consumers with an internal locus of control are more prone to let NEP result in behaviour consistent with this particular world view. From a theoretical perspective, our study lends support to previous assumptions and studies that have argued for locus of control as a factor that either strengthens or weakens the effect of predictor variables on behaviour (e.g., [36]). We will argue that being able to do something is alone not a sufficient reason to actually do it, but when motivated to do something, believing that you are also able to do it will amplify the effect of motivation. For marketing practitioners and public policy-makers, this implies that focusing on designing messages aimed at motivating pro-environmental behaviour would benefit from addressing the ease of actually contributing to a sustainable future and also focus on overarching sustainability issues that are in line with the idea of NEP and solutions (i.e., behavioural changes) that consumers will find possible to pursue.

Third, we did not find self-construal to moderate the effect of NEP on pro-environmental behaviour. While discussing nonsignificant results may border to speculations, we still offer a possible explanation that might serve as a pathway for future research. We argued that interdependents, whose overarching sustainability concerns such as NEP would be an important part of their self-image, would be more prone to behave in line with this as the public component of the self is important [40,44], as is self-image consistent behaviour. We do not find that NEP affects the behaviour among interdependents differently than the effect on behaviour among independents; this may be caused by them being equally prone to perform NEP-consistent behaviour, but for different reasons. The independents may be motivated to behave in line with their NEP-related beliefs, not because they care for others, but because they will behave so no matter what others think. An alternative explanation unrelated to individual personality differences is that we often make consumer decisions based on a few, important choice criteria. If acting "green", or sustainable, is not among the important criteria, we are not likely to choose "green" whether we are independent or interdependent. However, it is outside the empirical scope of this paper to draw a conclusion like that, but we believe a closer look at interdependents and independents, and the underlying explanation here is worth a further exploration. 
Limitations and Avenues for Future Research

The primary limitation of our work lies in the project's cross-sectional design, as this approach does not allow us to make causal inferences [69]. Yet, Bagozzi and Yi [70] urge researchers not to prematurely dismiss survey research as providing no support whatsoever for causal arguments. Still, future endeavours aiming at replicating, validating and/or further extending the presented findings would be highly informative if they apply, for instance, longitudinal and/or experimental research designs that satisfies also the temporal precedence criteria in causal research. Moreover, considered from a cultural perspective, a compelling strand of literature suggests that when it comes to, for instance, one's image of self (i.e., self-construal), the independent self is assumed to predominate in Western cultures, whereas the interdependent self is more prevalent in non-Western cultures [40,71]. Since all the participants enrolled to this project come from Norway, future inquiries are urged to explicitly examine cross-cultural variations in consumers' discrepancies between what they say and actually do to minimize their environmental footprint. Overall, in spite of these limitations, this research offers novel insights that shed further light on how environmental beliefs translate into consistent actions that effectively reduce environmental impact.

Author Contributions: Conceptualization, formal analysis, investigation, methodology, writing —original draft, writing—review and editing: L.A.D., A.H.G., H.H. and H.S. All authors have read and agreed to the published version of the manuscript.

Funding: This research received no external funding.

Conflicts of Interest: The authors declare no conflict of interest.

\section{Appendix A}

The list of measurement items

\section{Locus of Control}

1. I have often found that what is going to happen will happen.

2. Many times, we might just as well decide what to do by flipping a coin.

3. Who gets to be the boss often depends on who was lucky enough to be in the right place first.

4. Most people do not realize the extent to which their lives are controlled by accidental happenings.

5. Many times, I feel that I have little influence over the things that happen to me.

\section{Self-Construal}

1. I will sacrifice my self-interest for the benefit of the group I am in.

2. It is important to me to respect decisions made by the group.

3. I have respect for authority figures with whom I interact.

4. I should take into consideration my parents' advice when making education/career plans.

5. I respect people who are modest about themselves.

6. It is important for me to maintain harmony within my group.

New Ecological Paradigm

1. We are approaching the limit of the number of people the earth can support.

2. Humans have the right to modify the natural environment to suit their needs (r).

3. When humans interfere with nature, it often produces disastrous consequences.

4. Human ingenuity will ensure that we do NOT make the earth unlivable (r).

5. Humans are severely abusing the environment.

6. The earth has plenty of natural resources if we just learn how to develop them (r).

7. Plants and animals have as much right as humans to exist. 
8. The balance of nature is strong enough to cope with the impacts of modern industrial nations (r).

9. Despite our special abilities, humans are still subject to the laws of nature.

10. The so-called ecological crisis facing humankind has been greatly exaggerated (r).

11. The earth is like a spaceship with very limited room and resources.

12. Humans were meant to rule over the rest of nature $(r)$.

13. Humans will eventually learn enough about how nature works to be able to control it (r).

14. The balance of nature is very delicate and easily upset.

15. If things continue on their present course, we will soon experience a major ecological catastrophe.

\section{Pro-Environmental Behaviours}

Now we would like you to think about the last 12 months. How often have you decisively chosen to do some of the following in order to protect environment:

\section{A. Travelling Behaviour}

1. Chosen to travel by train or bus instead of flying.

2. Chosen not to travel somewhere to limit the number of airline flights you make.

3. Chosen a type of holiday with a low environmental footprint.

\section{B. Purchasing Behaviour}

1. Moved from one product to another.

2. Bought products with less plastic packaging.

3. Bought locally produced food.

4. Avoided buying products from a company that you believe had effect on the environment.

\section{Day-to-Day Activities}

1. Eaten leftover food.

2. Eaten vegetarian/vegan food.

3. Taken shorter showers to save on water.

4. Brought shopping bags from home while going to the shop.

5. Sorted out glass and metal from other waste.

\section{References}

1. Alwitt, L.F.; Pitts, R.E. Predicting Purchase Intentions for an Environmentally Sensitive Product. J. Consum. Psychol. 1996, 5, 49-64. [CrossRef]

2. Carrington, M.J.; Neville, B.A.; Whitwell, G.J. Why Ethical Consumers Don't Walk Their Talk: Towards a Framework for Understanding the Gap between the Ethical Purchase Intentions and Actual Buying Behaviour of Ethically Minded Consumers. J. Bus. Ethics 2010, 97, 139-158. [CrossRef]

3. Grimmer, M.; Miles, M.P. With the Best of Intentions: A Large Sample Test of the Intention-Behaviour Gap in Pro-Environmental Consumer Behaviour. Int. J. Consum. Stud. 2017, 41, 2-10. [CrossRef]

4. Juvan, E.; Dolnicar, S. The Attitude-Behaviour Gap in Sustainable Tourism. Ann. Tour. Res. 2014, 48, 76-95. [CrossRef]

5. Wiederhold, M.; Martinez, L.F. Ethical Consumer Behaviour in Germany: The Attitude-Behaviour Gap in the Green Apparel Industry. Int. J. Consum. Stud. 2018, 42, 419-429. [CrossRef]

6. Schiffman, L.G.; Kanuk, L.; Hansen, H. Consumer Behaviour - A European Outlook, 2nd ed.; Pearson Education Limited: Harlow, UK, 2012.

7. Gupta, S.; Ogden, D.T. The Attitude-Behaviour Gap in Environmental Consumerism. In Proceedings of the ABUBEF, Brundi, South Africa, 7 September 2006; pp. 199-205. 
8. Newton, P.; Meyer, D. Exploring the Attitudes-Action Gap in Household Resource Consumption: Does “Environmental Lifestyle" Segmentation Align with Consumer Behaviour? Sustainability 2013, 5, 1211-1233. [CrossRef]

9. Tarfaoui, D.; Zkim, S. Ecological Attitude- Behavior Gap: A Theoretical Analysis. Int. J. Econ. Strategy Manag. Bus. Process. 2017, 8, 33-38.

10. Dunlap, R.E.; Liere, K.D.V. The “New Environmental Paradigm”. J. Environ. Educ. 1978, 9, 10-19. [CrossRef]

11. Polonsky, M.J.; Vocino, A.; Grimmer, M.; Miles, M.P. The Interrelationship between Temporal and Environmental Orientation and Pro-Environmental Consumer Behaviour. Int. J. Consum. Stud. 2014, 38, 612-619. [CrossRef]

12. Brick, C.; Lewis, G.J. Unearthing the "Green" Personality: Core Traits Predict Environmentally Friendly Behavior. Environ. Behav. 2016, 48, 635-658. [CrossRef]

13. Pavalache-Ilie, M.; Cazan, A.-M. Personality Correlates of Pro-Environmental Attitudes. Int. J. Environ. Health Res. 2018, 28, 71-78. [CrossRef] [PubMed]

14. Milfont, T.L.; Sibley, C.G. The Big Five Personality Traits and Environmental Engagement: Associations at the Individual and Societal Level. J. Environ. Psychol. 2012, 32, 187-195. [CrossRef]

15. Li, D.; Zhao, L.; Ma, S.; Shao, S.; Zhang, L. What Influences an Individual's Pro-Environmental Behavior? A Literature Review. Resour. Conserv. Recycl. 2019, 146, 28-34. [CrossRef]

16. Steg, L.; Vlek, C. Encouraging Pro-Environmental Behaviour: An Integrative Review and Research Agenda. J. Environ. Psychol. 2009, 29, 309-317. [CrossRef]

17. Balundè, A.; Perlaviciute, G.; Steg, L. The Relationship between People's Environmental Considerations and Pro-Environmental Behavior in Lithuania. Front. Psychol. 2019, 10. [CrossRef] [PubMed]

18. Stern, P.C. Toward a Coherent Theory of Environmentally Significant Behavior. J. Soc. Issues 2000, 523-530. [CrossRef]

19. Ajzen, I. The Theory of Planned Behavior. Organ. Behav. Hum. Decis. Process. 1991, 50, 179-211. [CrossRef]

20. Lutz, R.J. The Role of Attitude Theory in Marketing. In Perspectives in Consumer Behaviour; Kassarjian, H.H., Robertson, T.S., Eds.; Prentice Hall: Englewood Cliffs, NJ, USA, 1991; pp. 233-250.

21. Xiao, C.; Buhrmann, J. The Structure and Coherence of the New Environmental Paradigm: Reconceptualizing the Dimensionality Debate. HER 2017, 23, 179-198. [CrossRef]

22. Festinger, L. A Theory of Cognitive Dissonance; Stanford University Press: Redwood City, CA, USA, 1957; ISBN 978-0-8047-0131-0.

23. Heider, F. The Psychology of Interpersonal Relations; John Wiley \& Sons Inc: Hoboken, NJ, USA, 1958.

24. Xiao, C.; Dunlap, R.E.; Hong, D. Ecological Worldview as the Central Component of Environmental Concern: Clarifying the Role of the NEP. Soc. Nat. Resour. 2019, 32, 53-72. [CrossRef]

25. Osburg, V.-S.; Yoganathan, V.; Brueckner, S.; Toporowski, W. How Detailed Product Information Strengthens Eco-Friendly Consumption. Manag. Decis. 2019, 58, 1084-1099. [CrossRef]

26. Johnson, B.; Eagly, A. Effects of Involvement on Persuasion: A Meta-Analysis. Psychol. Bull. 1989, 106, 290. [CrossRef]

27. Stern, P.C.; Dietz, T.; Guagnano, G.A. The New Ecological Paradigm in Social-Psychological Context. Environ. Behav. 1995, 27, 723-743. [CrossRef]

28. Pahl, S.; Harris, P.R.; Todd, H.A.; Rutter, D.R. Comparative Optimism for Environmental Risks. J. Environ. Psychol. 2005, 25, 1-11. [CrossRef]

29. Wurzinger, S.; Johansson, M. Environmental Concern and Knowledge of Ecotourism among Three Groups of Swedish Tourists. J. Travel Res. 2006, 45, 217-226. [CrossRef]

30. Hedlund, T. The Impact of Values, Environmental Concern, and Willingness to Accept Economic Sacrifices to Protect the Environment on Tourists' Intentions to Buy Ecologically Sustainable Tourism Alternatives. Tour. Hosp. Res. 2011, 11, 278-288. [CrossRef]

31. Mair, J. Exploring Air Travellers' Voluntary Carbon-Offsetting Behaviour. J. Sustain. Tour. 2011, 19, $215-230$. [CrossRef]

32. Lefcourt, H.M. Locus of Control and the Response to Aversive Events. Can. Psychol. Rev. Psychol. Can. 1976, 17, 202-209. [CrossRef]

33. Rotter, J.B. Generalized Expectancies for Internal Versus External Control of Reinforcement. Psychol. Monogr. 1966, 80, 1-28. [CrossRef] 
34. Adler, A. Individual psychology. In Psychologies of 1930; International University Series in Psychology; Clark University Press: Worcester, MA, USA, 1930; pp. 395-405.

35. Miller, S.M. Why Having Control Reduces Stress: If I Can Stop the Roller Coaster, I don't Want to Get Off. Hum. Help. Theory Appl. 1980, 71-95. [CrossRef]

36. Mehl, E.; Hansen, H. The Effect of Personality on Salespeople's Information Gathering. Balt. J. Manag. 2017, 12, 464-484. [CrossRef]

37. McCarty, J.A.; Shrum, L.J. The Influence of Individualism, Collectivism, and Locus of Control on Environmental Beliefs and Behavior. J. Public Policy Mark. 2001, 20, 93-104. [CrossRef]

38. Gardner, W.L.; Gabriel, S.; Lee, A.Y. "I" Value Freedom, but "We" Value Relationships: Self-Construal Priming Mirrors Cultural Differences in Judgment. Psychol. Sci. 2016. [CrossRef]

39. Iyengar, S.S.; Lepper, M.R. Rethinking the Value of Choice: A Cultural Perspective on Intrinsic Motivation. J. Personal. Soc. Psychol. 1999, 76, 349-366. [CrossRef]

40. Markus, H.; Kitayama, S. Culture and the Self: Implications for Cognition, Emotion, and Motivation. Psychol. Rev. 1991, 98, 224-253. [CrossRef]

41. Schweder, R.; Bourne, E. Does the Concept of the Person Vary cross culturally? In Cultural Conceptions of Mental Health and Therapy, Reidel, Boston; Marsella, A., White, G., Eds.; D. Reidel Publishing Company: Dordrecht, The Netherlands, 1982.

42. Kim, H.; Markus, H. Deviance or Uniqueness, Harmony or Conformity? A Cultural Analysis. J. Pers. Soc. Psychol. 1999, 77, 785-800. [CrossRef]

43. Pöhlmann, C.; Carranza, E.; Hannover, B.; Iyengar, S. Repercussions of Self?Construal for Self?Relevant and Other?Relevant Choice. Soc. Cogn. 2007, 25, 284-305. [CrossRef]

44. Chen, Y.; Moosmayer, D.C. When Guilt is Not Enough: Interdependent Self-Construal as Moderator of the Relationship Between Guilt and Ethical Consumption in a Confucian Context. J. Bus. Ethics 2020, 161, 551-572. [CrossRef]

45. Argo, J.J.; Dahl, D.W. Social Influence in the Retail Context: A Contemporary Review of the Literature. J. Retail. 2019. [CrossRef]

46. Vaske, J.J.; Beaman, J.; Sponarski, C.C. Rethinking Internal Consistency in Cronbach's Alpha. Leis. Sci. 2017, 39, 163-173. [CrossRef]

47. Singelis, T.M. The Measurement of Independent and Interdependent Self-Construals. Pers. Soc. Psychol. Bull. 1994, 20, 580-591. [CrossRef]

48. Dunlap, R.E.; Liere, K.D.V.; Mertig, A.G.; Jones, R.E. New Trends in Measuring Environmental Attitudes: Measuring Endorsement of the New Ecological Paradigm: A Revised NEP Scale. J. Soc. Issues 2000, 56, 425-442. [CrossRef]

49. Vikan, A.; Camino, C.; Biaggio, A.; Nordvik, H. Endorsement of the New Ecological Paradigm. Environ. Behav. 2007, 39, 217-228. [CrossRef]

50. Diekmann, A.; Preisendörfer, P. Persónliches Umweltverhalten: Diskrepanzen Zwischen Anspruch und Wirklichkeit. Ecology in everyday life: Inconsistencies between environmental attitudes and behavior. Kölner Z. für Soziologie Soz. 1992, 44, 226-251.

51. Steg, L.; Bolderdijk, J.W.; Keizer, K.; Perlaviciute, G. An Integrated Framework for Encouraging Pro-Environmental Behaviour: The Role of Values, Situational Factors and Goals. J. Environ. Psychol. 2014, 38, 104-115. [CrossRef]

52. Hayes, A.F. Introduction to Mediation, Moderation, and Conditional Process Analysis: A Regression-Based Approach; Guilford Press: New York, NY, USA, 2013; ISBN 978-1-60918-230-4.

53. Micceri, T. The Unicorn, the Normal Curve, and Other Improbable Creatures. Psychol. Bull. 1989, $105,156$. [CrossRef]

54. Spiller, S.A.; Fitzsimons, G.J.; Lynch, J.G., Jr.; McClelland, G.H. Spotlights, Floodlights, and the Magic Number Zero: Simple Effects Tests in Moderated Regression. J. Mark. Res. 2013, 50, 277-288. [CrossRef]

55. Podsakoff, P.M.; MacKenzie, S.B.; Lee, J.-Y.; Podsakoff, N.P. Common Method Biases in Behavioral Research: A Critical Review of the Literature and Recommended Remedies. J. Appl. Psychol. 2003, 88, 879-903. [CrossRef]

56. Podsakoff, P.M.; MacKenzie, S.B.; Podsakoff, N.P. Sources of Method Bias in Social Science Research and Recommendations on How to Control It. Annu. Rev. Psychol. 2012, 63, 539-569. [CrossRef] 
57. MacKenzie, S.B.; Podsakoff, P.M. Common Method Bias in Marketing: Causes, Mechanisms, and Procedural Remedies. J. Retail. 2012, 88, 542-555. [CrossRef]

58. Tourangeau, R.; Rips, L.J.; Rasinski, K. The Psychology of Survey Response; Cambridge University Press: New York, NY, USA, 2000; ISBN 978-0-521-57246-0.

59. Vishwanath, A. Common Method Bias. In The International Encyclopedia of Communication Research Methods; American Cancer Society: Atlanta, GA, USA, 2017; pp. 1-5. ISBN 978-1-118-90173-1.

60. Podsakoff, P.M.; Organ, D.W. Self-Reports in Organizational Research: Problems and Prospects. J. Manag. 1986, 12, 531-544. [CrossRef]

61. Hayes, A.F.; Rockwood, N.J. Regression-Based Statistical Mediation and Moderation Analysis in Clinical Research: Observations, Recommendations, and Implementation. Behav. Res. Ther. 2017, 98, 39-57. [CrossRef] [PubMed]

62. Hayes, A.F.; Montoya, A.K. A Tutorial on Testing, Visualizing, and Probing an Interaction Involving a Multicategorical Variable in Linear Regression Analysis. Commun. Methods Meas. 2017, 11, 1-30. [CrossRef]

63. Krishna, A. A Clearer Spotlight on Spotlight: Understanding, Conducting and Reporting. J. Consum. Psychol. 2016, 26, 315-324. [CrossRef]

64. Ellis, P.D. The Essential Guide to Effect Sizes: Statistical Power, Meta-Analysis, and the Interpretation of Research Results; Cambridge University Press: Cambridge, UK, 2010; ISBN 978-1-139-48815-0.

65. Caruana, R.; Carrington, M.J.; Chatzidakis, A. "Beyond the Attitude-Behaviour Gap: Novel Perspectives in Consumer Ethics": Introduction to the Thematic Symposium. J. Bus. Ethics. 2016, 136, 215-218. [CrossRef]

66. Farjam, M.; Nikolaychuk, O.; Bravo, G. Experimental Evidence of an Environmental Attitude-Behavior Gap in High-Cost Situations. Ecol. Econ. 2019, 166, 106434. [CrossRef]

67. Kollmuss, A.; Agyeman, J. Mind the Gap: Why Do People Act Environmentally and What Are the Barriers to Pro-Environmental Behavior? Environ. Educ. Res. 2002, 8, 239-260. [CrossRef]

68. Barnett, J.; Horlick-Jones, T.; Rosenhead, J.; Prades, A.; Espluga-Trenc, J.; Konrad, W.; Poumadère, M.; Constantin, M.; Enander, A. Evidence about the Policy Assumptions about Lay Behaviour; Deliverable 3.1 PACHELBEL FP7 Project, European Commision 7th Framework Programme. 2010. Available online: www.pachelbel.eu/scientific-publications.aspx (accessed on 17 September 2020).

69. Shadish, R.; Cook, D.; Campbell, D. Experimental and Quasi-Experimental Designs for Generalized Causal Inference; Wadsworth Publishing: London, UK, 2002.

70. Bagozzi, R.P.; Yi, Y. Specification, Evaluation, and Interpretation of Structural Equation Models. J. Acad. Mark. Sci. 2012, 40, 8-34. [CrossRef]

71. Cross, S.E.; Hardin, E.E.; Gercek-Swing, B. The What, How, Why, and Where of Self-Construal. Pers. Soc. Psychol. Rev. 2011, 15, 142-179. [CrossRef] 